\title{
Boldine Activates Intrinsic Apoptotic Pathway in DU-145 Androgen-Independent Prostate Cancer Cell Line
}

\author{
Cardile Venera ${ }^{1}$, Avola Rosanna ${ }^{1}$, C.E. Graziano Adriana ${ }^{1}$, Madrid Alejandro ${ }^{2}$ and \\ Russo Alessandra, ${ }^{3, *}$
}

${ }^{1}$ Department of Biomedical and Biotechnological Sciences, University of Catania, Via S. Sofia, 89, 95123 Catania, Italy

${ }^{2}$ Departamento de Química, Facultad de Ciencias Naturales y Exactas, Universidad de Playa Ancha, Avda. Leopoldo Carvallo 270, Playa Ancha, Valparaíso 2340000, Chile

${ }^{3}$ Department of Drug Sciences, University of Catania, Via S. Sofia 64, 95125 Catania, Italy

\begin{abstract}
Prostate cancer is one of the most common forms of cancer in men and continues to be a problem in the developed world. The treatment approaches for androgen-independent prostate cancer are unsatisfactory and the survival of those patients remains poor. Thus, there is a strong demand to develop novel therapeutic agents to treat and prevent this advanced malignancy. The present study evaluated the effect of boldine (2,9-dihydroxy-1,10-dimethoxyaporphine), an aporphine alkaloid occurs abundantly in the leaves of Boldo (Peumus boldus Molina), on growth and cell death of DU-145 androgen-independent prostate cancer cell line. The cell viability was measured by MTT test and LDH release was used to quantify necrosis cell death. Genomic DNA, caspase-3 activity, expression of cleaved caspase-9, $\mathrm{Hsp} 70, \mathrm{Bcl}-2$ and Bax proteins were analyzed in order to study the apoptotic process. The results showed that boldine was able to reduce cell viability in the range of $60-240 \mu \mathrm{M}$ concentrations, and suggest this aporphine alkaloid induces cell death by intrinsic apoptotic pathway that probably involves the down-regulation of heat shock protein 70 (Hsp70). In fact, an increase of caspase-3 enzyme activity and Bax protein expression, in conjunction with the more pronounced decrease in Bcl-2 occurred in DU-145 cells treated with boldine at $60-120 \mu \mathrm{M}$ concentrations. In addition, caspase- 9 was shown to be observably activated. Moreover, boldine such as quercetin, a well-known Hsp70 protein inhibitor, induced a reduction of Hsp70 expression. The hypothesis of apoptosis induction in our experimental conditions was reinforced by a high DNA fragmentation at 60-120 $\mu \mathrm{M}$ concentrations, not correlated to LDH release. The present findings, starting point for further investigation, suggest that boldine structure might be used to design novel derivatives for the developing of potential new drugs for advanced prostate cancer therapy.
\end{abstract}

Keywords: Aporphine alkaloid, prostate cancer, DNA damage, Bcl-2 family proteins, heat shock protein 70.

\section{INTRODUCTION}

Prostate cancer is one of the most common forms of cancer in men and continues to be a problem in the developed world [1]. In fact, it is the second leading cause of death amongst older men in western countries such as Europe and the United States, while its incidence is low in Asian countries [1]. The causes of prostate cancer are largely unknown. However, the most recognized origin of this frequently occurring disease appear mainly correlated to a shift toward western diets and lifestyles. Recent research also suggests that obesity increases the risk of prostate cancer [2, 3]. Another is considered to be altered gene expression in patients due to environmental factors [2, 3]. Conventional therapies such as radical prostatectomy, radiotherapy and hormonal therapy are effective options to treat localized disease at an early stage, but clinical treatment of advanced prostate cancers has been hard [3, 4]. In normal prostate tissue, androgens regulate the growth and differentiation of

*Address correspondence to this author at the Department of Drug Sciences, University of Catania, Via S. Sofia 64, 95125, Catania, Italy; Tel: +39095 7384073; Fax: +39 095 7384220; E-mail: alrusso@unict.it; ales0303@libero.it epithelial cells. At first, hormone therapy, either decreasing circulating androgens or by inhibiting the androgen receptor using antagonists, for patients with advanced and aggressive prostate cancer in general reaches good success with a high response rate of 80 $90 \%$ [5]. However, in advanced stages, growth and development generally become refractory to androgen effects progressing to metastatic and ultimately fatal prostate cancer. In fact, most patients receiving androgen ablation progress to a hormone-refractory state several years after the initial therapy, eventually making them unresponsive to further hormonal treatment and leads to a fatal outcome in many cases $[6,7]$. Moreover, chemotherapy and radiation therapy are usually inadequate against advanced prostate cancer, and exhibit severe toxic side effects [8, 9]. Therefore, there is a strong demand to develop novel therapeutic agents to treat and prevent this advanced malignancy. In this regard, active compounds found in plants with diversified biological properties have shown promising responses for the prevention and/or intervention of prostate cancer [10]. In fact, the vast structural diversity of molecules found in plants provides unique opportunities for discovering new drugs that rationally target the abnormal molecular and 
biochemical signals leading to cancer. Experience from ethnomedicine, together with extensive basic laboratory findings, have shown for many years that phytochemicals could play a key role in cancer prevention and treatment. Boldo, the dried leaf of Peumus boldus Molina (Monimiaceae), an evergreen shrub or a small tree growing in central and southern Chile, has been used for its medicinal properties by diverse indigenous groups, including the Mapuche ethnia who lived in Chile before the arrival of the Spanish in the fifteenth century [11]. Actually, Boldo is widely used in Chilean folk medicine and is recognised as a medicinal herb in Pharmacopoeia [11]. Introduced in France in about 1870 by Bourgoin and Verne, this species is described in the French Pharmacopoeia. It is also included in the Pharmacopoeias of Switzerland, Germany, Brazil, Chile, Portugal, Rumania and Spain $[11,12]$. Pharmacognostical texts, pharmacopoeias and hand books list the therapeutic uses as cholagogue, choleretic, digestive disturbances, diuretic, hepatic stimulant and stomachic. Besides these main indications, Boldo for its active components is also used for the treatment of urinary tract inflammation [11, 12]. Boldine (2,9-dihydroxy-1,10-dimethoxy-aporphine) (Figure 1), an aporphine alkaloid, occurs abundantly in Boldo, has been shown to have a number of potential pharmacological activities in vitro and in vivo, including antinflammatory and anticancer properties [13, 14]. In particular, it has been reported that boldine is able to inhibit cell growth of bladder carcinoma cell lines [14]. In view of these considerations, in the course of our continuing search for new anticancer compounds for prevention and/or treatment of cancer, this study was designed to investigate the effects of boldine on the growth of androgen-independent prostate cancer cells (DU-145) and to explore the possible mechanisms of action.

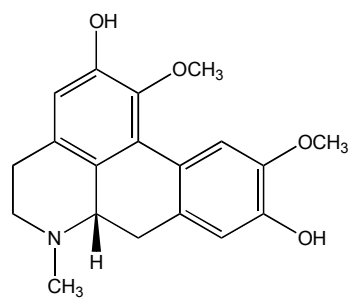

Figure 1: The structure of 2,9-dihydroxy-1,10-dimethoxy aporphine, boldine.

\section{MATERIALS AND METHODS}

\section{Chemical and Reagents}

All reagents were of commercial quality and were used as received. Boldine (2,9-dihydroxy-1,10dimethoxy-aporphine) was purchased from Sigma-
Aldrich (Sigma Aldrich Co, St. Louis, USA). Dimethyl sulfoxide (DMSO), hydrogen peroxide solution (30\% (w/w) in $\mathrm{H}_{2} \mathrm{O}_{2}$ ), 3(4,5-dimethylthiazol-2-yl)2,5-diphenyltetrazolium bromide (MTT) and $\beta$-nicotinamide-adenine dinucleotide $(\mathrm{NADH})$ were purchased from Sigma Chemical Co. (St. Louis, MO, USA). All other chemicals were purchased from Sigma Aldrich Co (St. Louis, USA), GIBCO BRL Life Technologies (Grand Island, NY, USA) and Santa Cruz Biotechnology (Santa Cruz, $\mathrm{CA})$.

\section{Cell Culture and Treatments}

Human prostate cancer androgen-non responsive DU-145 cells obtained from American Type Culture Collection (Rockville, MD, USA), were maintained in Earle Minimal Essential Medium (EMEM), containing $10 \%$ fetal calf serum, $1 \mathrm{mM} \mathrm{L-glutamine,} \mathrm{antibiotics} \mathrm{(50}$ $\mathrm{IU} / \mathrm{ml}$ penicillin and $50 \mathrm{\mu g} / \mathrm{ml}$ streptomycin) and $1 \%$ non essential aminoacids. Normal human non-immortalised buccal fibroblast cells, kindly donated by Institute IGB, CNR (Naples, Italy), were grown in Dulbecco's modified Eagle's medium (DMEM) supplemented with $10 \%$ fetal calf serum (FCS), $100 \mathrm{U} / \mathrm{ml}$ penicillin, 100 $\mu \mathrm{g} / \mathrm{ml}$ streptomycin, and $25 \mu \mathrm{g} / \mathrm{ml}$ fungizone. The cells were plated at a constant density to obtain identical experimental conditions in the different tests, thus to achieve a high accuracy of the measurements. In the MTT assay, cancer cells were plated at $6 \times 10^{3}$ cells per well in a 96-well flat-bottomed $200 \mu \mathrm{L}$ microplate, and at $2 \times 10^{4}$ cells per well for normal human nonimmortalised buccal fibroblast cells, in a 96-well flatbottomed $200 \mu \mathrm{l}$ microplate. In other tests, cells were plated at $8 \times 10^{5}$ cells $(2 \mathrm{ml})$ per $35 \mathrm{~mm}$ culture dish. After 24 hours incubation at $37{ }^{\circ} \mathrm{C}$ under a humidified $5 \%$ carbon dioxide to allow cell attachment, the cells were treated with different concentrations of boldine, and incubated for 72 hours under the same conditions. In our experimental conditions, the concentrations used in the different assays (60-120-240 $\mu \mathrm{M}$ ) were chosen since no significant effect of pure compound has ever been observed at lower dosage.

Stock solution of compound was prepared in dimethylsulfoxide (DMSO) and the final concentration of this solvent was kept constant at $0.25 \%$. Control cells received DMSO alone. In assays Lactate Dehydrogenase (LDH) Release, Activity of Caspase-3, and DNA Analysis, hydrogen peroxide $\left(\mathrm{H}_{2} \mathrm{O}_{2}\right)(30 \%$ w/w, Sigma Aldrich Co., St. Louis, MS, USA) was used as a positive control. 


\section{MTT Bioassay}

MTT assay was performed as described previously [15]. Four hours before the end of the treatment time, $20 \mu \mathrm{l}$ of $0.5 \% 3(4,5$-dimethyl-thiazol-2-yl)2,5-diphenyltetrazolium bromide (MTT) in phosphate buffer saline (PBS) were added to each microwell. Cells were washed once before adding MTT. After four hours of incubation at $37^{\circ} \mathrm{C}$, the supernatant was removed and replaced with $100 \mu \mathrm{l}$ of DMSO. The optical density of each well sample was measured with a microplate spectrophotometer reader at $550 \mathrm{~nm}$.

\section{Lactate Dehydrogenase (LDH) Release}

LDH activity was spectrophotometrically measured in the culture medium and in the cellular lysates at 340 $\mathrm{nm}$ by analyzing NADH reduction during the pyruvatelactate transformation, as previously reported [15]. The percentage of $\mathrm{LDH}$ released was calculated as percentage of the total amount, considered as the sum of the enzymatic activity present in the cellular lysate and that in the culture medium.

\section{Activity of Caspase-3}

The activity of caspase- 3 was determined by using the Caspase colorimetric assay Kit (SIGMA RBI, St. Louis, MS, USA), as previously described [15].The total protein content, used to reflect cell number and measured according to Bradford, 1976 [16], was evaluated for each sample, and the results are reported as $\mathrm{OD}_{405} \mathrm{~nm} / \mathrm{mg}$ protein and compared to relative control.

\section{DNA Analysis by COMET Assay}

The presence of DNA fragmentation was examined by single cell gel electrophoresis (COMET assay), as previously reported [15].

\section{TUNEL Assay (Apo Alert® DNA Fragmentation Assay)}

The nuclear DNA fragmentation was evaluated by a commercial kit (Apo Alert@ DNA fragmentation Assay, Clontech Laboratories, Inc.) in accordance with the manufacturer's instructions. The Apo Alert ${ }^{\circledR}$ DNA fragmentation assay kit detects apoptosis-induced nuclear DNA fragmentation via a fluorescence assay.

\section{Western Blot Analysis}

The expression of Bcl-2, Bax, cleaved caspase-9 and Hsp70proteins was evaluated by Western blot analysis, as previously described [15]. Bcl-2 (SAB2500154, Sigma Aldrich) (1:500 dilution), -Bax (B3428, Sigma Aldrich) (1:2000 dilution), -cleaved caspase-9 (AB3629, Sigma Aldrich) (1:500 dilution), Hsp70 (4G4, sc-59569; Santa Cruz Biotechnology) (1:300 dilution) and a-tubulin (T5326; Sigma Aldrich) (1:5000 dilution) antibodies were diluted in TBST and membranes incubated for two hours at room temperature. Antibodies were detected with horseradish peroxidase-conjugated secondary antibody using the enhanced chemiluminescence detection Supersignal West Pico Chemiluminescent Substrate (Pierce Chemical Co., Rockford, IL, USA). Bands were measured densitometrically by ImageJ software and their relative density calculated based on the density of the $\alpha$-tubulin bands in each sample. Values were expressed as arbitrary densitometric units corresponding to signal intensity.

\section{Statistical Analysis}

Representative data from three independent experiments, performed in quadruplicate, are shown and quantitated, and represented as mean \pm standard deviation (SD). Results were analyzed using one-way ANOVA followed by Dunnett's post-hoc test for multiple comparisons with control. All statistical analyses were performed using the statistical software package SYSTAT, version 9 (Systat Inc., Evanston, IL, USA).

\section{RESULTS}

\section{Cell Growth Inhibitory Effect of Boldine}

To determine the effect of boldine (Figure 1) on prostate cancer cells, androgen-independent DU-145 cells were treated with boldine at different concentrations (30-240 $\mu \mathrm{M}$ concentrations) for 72 hours, and MTT assay was performed to measure the cell growth. As demonstrated in Figure 2, treatment with boldine (60-240 $\mu \mathrm{M}$ concentrations) resulted in a inhibitory effect on cell viability of prostate cancer cells. Interestingly, these concentrations, did not reveal cytotoxic effect against normal human buccal fibroblast cells (Figure 2), a cellular model used in toxicity studies [17].

\section{Induction of Cell Death}

$\mathrm{LDH}$ is a soluble enzyme located in the cytosol, that is released into the surrounding culture medium upon cell damage and lysis. LDH activity in the culture medium can, therefore, be used as an indicator of membrane integrity, and thus a measurement of 
cytotoxicity [18]. No statistically significant increase in $\mathrm{LDH}$ release (Table 1), was observed in cancer cells treated with boldine $(60-120 \mu \mathrm{M})$ and the positive control $\mathrm{H}_{2} \mathrm{O}_{2}(1 \mu \mathrm{M})$, a apoptotic inductor in cancer cell lines, when it is used at low concentrations [19]. Alternatively, we found a significant LDH release at higher concentration $(240 \mu \mathrm{M})$ (Table 1). Similar results were obtained with $\mathrm{H}_{2} \mathrm{O}_{2}(1000 \mu \mathrm{M})$, a necrotic inductor in cancer cell line, when it is used at high concentrations [20].

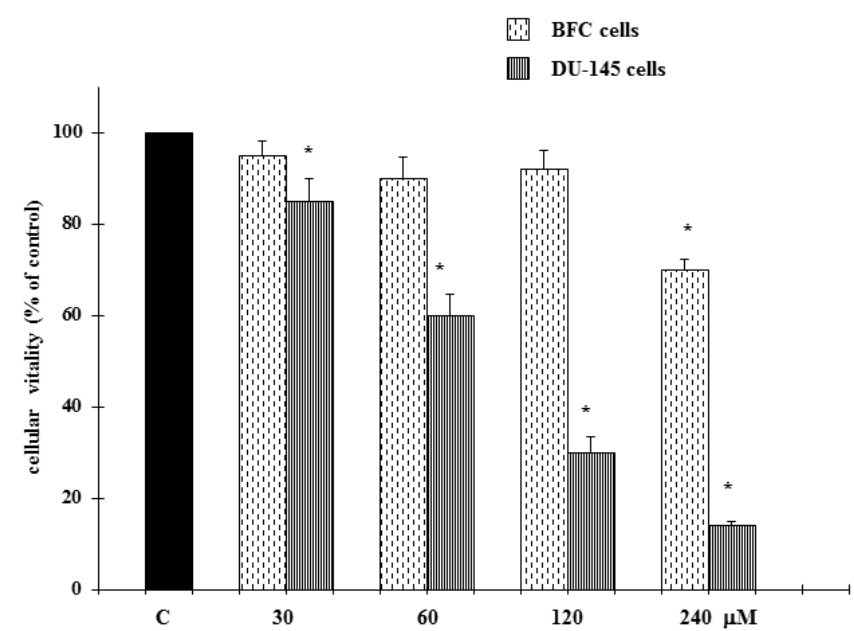

Figure 2: Cell growth inhibition, assayed using MTT test, of normal human non-immortalised buccal fibroblast cells (BFC) and DU-145 cells untreated and treated with boldine for 72 hours.

*Significant vs. control untreated cells $(p<0.001)$.

Table 1: Lactate dehydrogenase (LDH) release, expressed as percentage of LDH released into the cell medium with respect to total LDH in DU-145 cells untreated and treated with boldine at different concentrations for 72 hours

\begin{tabular}{|c|c|}
\hline Treatments & DU-145 \% LDH released \\
\hline Control & $5.6 \pm 0.6$ \\
\hline \multicolumn{2}{|l|}{$\mathrm{H}_{2} \mathrm{O}_{2}$} \\
\hline $1 \mu \mathrm{M}$ & $3.4 \pm 0.5$ \\
\hline $1000 \mu \mathrm{M}$ & $70 \pm 0.8^{*}$ \\
\hline \multicolumn{2}{|l|}{ Boldine } \\
\hline $30 \mu \mathrm{M}$ & $4.07 \pm 0.7$ \\
\hline $60 \mu \mathrm{M}$ & $4.81 \pm 0.6$ \\
\hline $120 \mu \mathrm{M}$ & $5.71 \pm 0.9$ \\
\hline $240 \mu \mathrm{M}$ & $39.1 \pm 0.8^{*}$ \\
\hline
\end{tabular}

The values are the mean \pm SD of three experiments performed in quadruplicate.

${ }^{*}$ The values were significant vs. control untreated cells $(p<0.001)$.
Dysregulation of apoptosis in cancer cells contributes to carcinogenesis and is involved in the resistance to cytotoxic anticancer drugs [21]. Therefore, the next experiments were performed to characterize the role of activation of caspase-3, the major executioner caspase in the caspase cascade [22]. As shown in Figure 3, caspase-3 activity was significantly increased in DU-145 cells treated for 72 hours with boldine (60-120 $\mu \mathrm{M}$ concentrations) and $\mathrm{H}_{2} \mathrm{O}_{2}(1 \mu \mathrm{M})$. Also the results obtained by Comet assay, expressed as TMOM values, suggest that this tested aporphine alkaloid, at concentrations of 60-120 $\mu \mathrm{M}$, triggers apoptotic cell death. In fact, Comet assay evidence typical comet-like structures that occur during apoptosis (Figure 4). TUNEL results confirm the apoptotic process. In fact, the treatment of cells with boldine, at 60-120 $\mu \mathrm{M}$ concentration (Figure 4B), induced a significant increase in green fluorescence, which is related to DNA fragmentation. These results suggest that boldine promoted apoptosis of DU-145 cells in a dose-dependent manner.

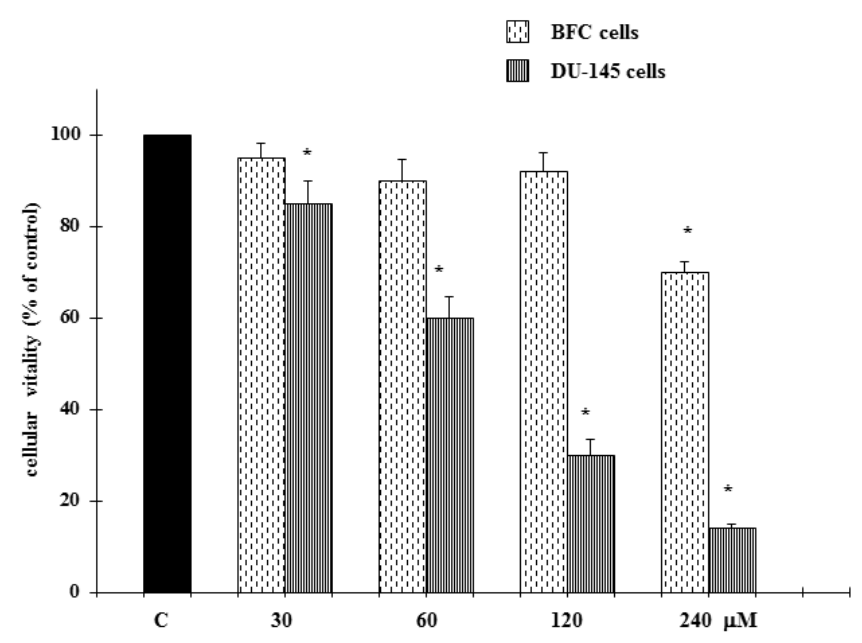

Figure 3: Caspase-3 activity in DU-145 cells untreated and treated for 72 hours with boldine. *Significant vs. control untreated cells $(p<0.001)$.

To further delineate the mechanism by which boldine induced apoptosis on DU-145 cells, the expression of apoptosis-associated proteins, such as Bax, Bcl-2 and cleaved caspase-9, was examined by Western blot assay. Boldine at 60-120 $\mu \mathrm{M}$ concentrations reduced anti-apoptotic protein $\mathrm{Bcl}-2$ and increased cleaved caspase-9 (Figure 5). Also, proapoptotic protein Bax was activated by boldine treatment in DU-145 cells (Figure 5), shifting the $\mathrm{Bax} / \mathrm{Bcl}-2$ ratio in favor of apoptosis (Figure 5B). These data indicate that boldine-induced apoptosis in DU-145 cells is mediated, at least in part, through the mitochondrial pathway. 


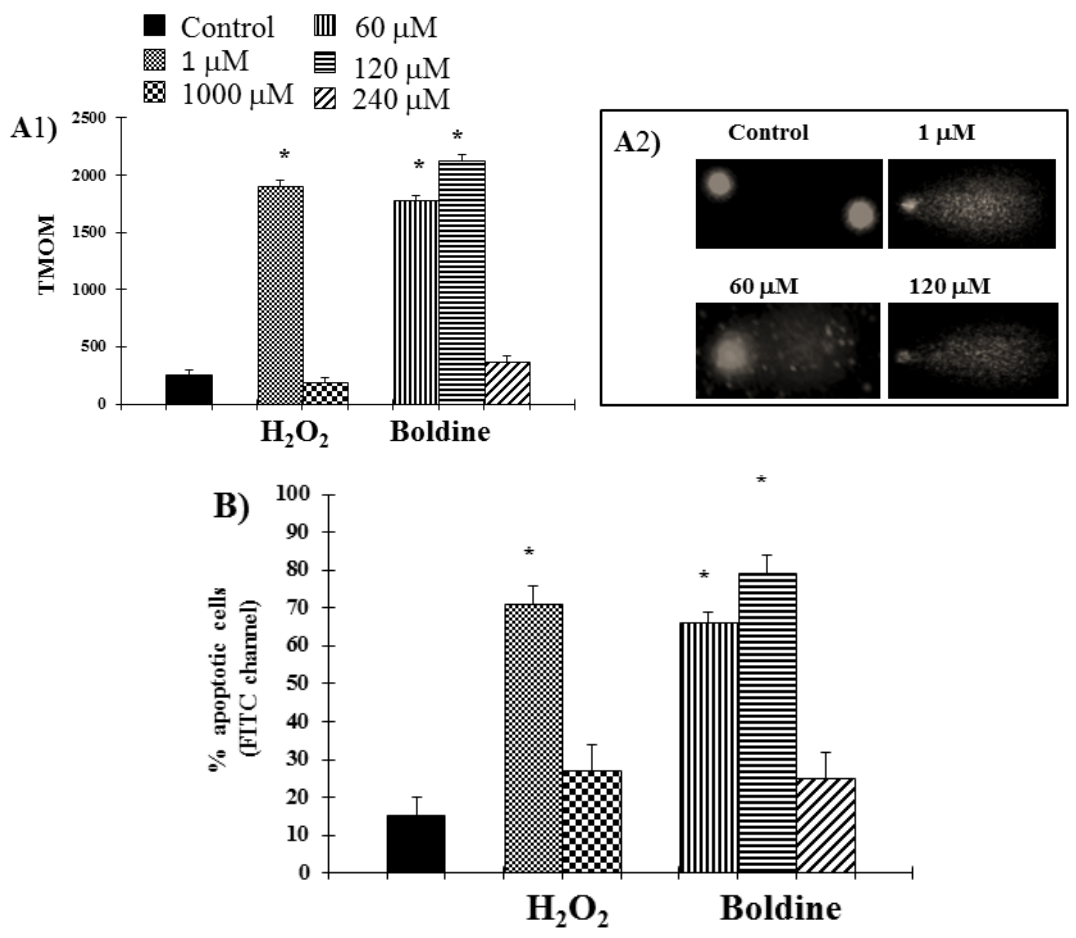

Figure 4: COMET A) and TUNEL B) assays in DU-145cells untreated and treated for 72 hours with boldine. A1) For COMET assays the values were expressed as TMOM, tail moment expressed as the product of TD (distance between head and tail) and TDNA. A2) Representative photomicrographs of microgel electrophoresed genomic DNA (COMET assay) of untreated and treated cancer cells. B) For TUNEL assay results were reported as percentage of apoptotic cells, obtained from the ratio between green (apoptotic cells) and red (total amount of cells) fluorescence measured by flow cytometry. ${ }^{*}$ Significant vs. control untreated cells $(p<0.001)$.

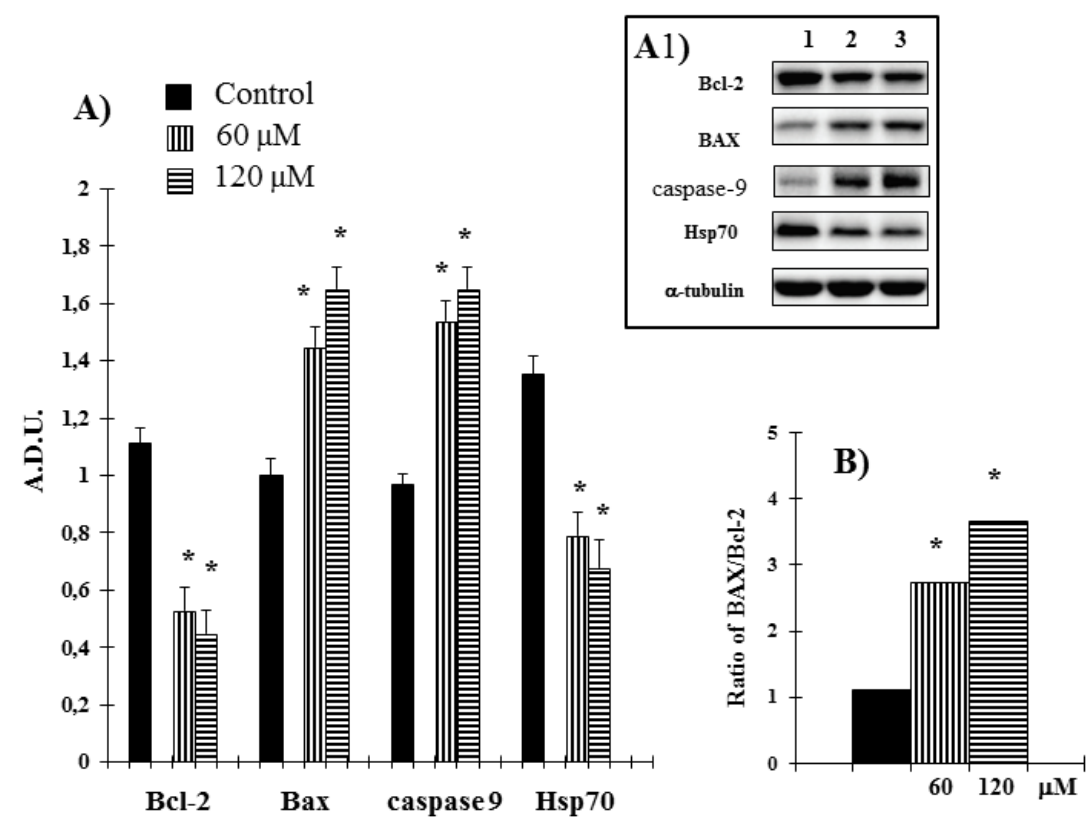

Figure 5: A1) Levels of Bcl-2, Bax, cleaved caspase-9 and Hsp70 proteins in DU-145 cells untreated and treated with boldine $(60-120 \mu \mathrm{M})$ for 72 hours. Values are expressed as arbitrary densitometric units (A.D.U.) corresponding to signal intensity present on the autoradiography of Western blots. A2) Representative blots of control (1) and boldine 60-120 $\mu \mathrm{M}(1-2)$. B) $\mathrm{Bax} / \mathrm{Bcl} 2$ ratio). ${ }^{*}$ Significant vs. control untreated cells $(p<0.001)$.

Hsp70 plays an important role in mediating chemoresistance in a variety of cancer cells [23], therefore in the present study a possible relationship between Hsp70 expression and cell death was also 
investigated. The data, reported in Figure 5, show a reduction of levels of this protein in cancer cells treated with boldine.

\section{DISCUSSION}

Several studies investigated the effects of boldine (Figure 1) on cancer cells. In particular, Noureini and Tanavar, 2015 [24] found that this natural compound significantly inhibited the cell viability of MDA-MB-231, MCF-7 and HEK293 cell lines. Interestingly, its cytotoxicity in normal human fibroblast cells was considerably lower than cancer cells [24]. These results are consistent with our findings. In fact, boldine inhibited the growth of DU-145 cell line, at concentrations non toxic for normal human nonimmortalised buccal fibroblast cells (Figure 2).

Present therapeutic interventions targeting a single key factor lead to the acquisition of drug resistance and relapse due to highly redundant and by passable signaling pathways [25]. Multi-target agents have attracted attention as potential therapeutic solutions to cancer and drug resistance $[26,27]$. As potential multitarget drugs, many substances present in plants, biologically active for cancer treatment [28], have multiple molecular targets while maintaining their beneficial broad target profile [26]. For example, molecules, such as curcumin and resveratrol are considered to be valuable leads for multitarget drugs [26]. As well-known, failure to undergo apoptosis has been implicated in tumor development and resistance to cancer therapy [21]. Curcumin and resveratrol trigger apoptotic cell death, inducing activation of caspase and PARP degradation [26]. Also the alkaloid boldine is a apoptotic inductor in cancer cells [24]. In particular, Paydar et al. 2014 reported that boldine selectively induced caspase- 9 and caspase-3/7 activation, Bcl-2 down regulation and Bax upregulation in MDA-MB-231 cell line [29]. Promotion of apoptosis in prostate cancer cells may lead to regression and improved prognosis of refractory disease [30]. Therefore, in view of these considerations, we next addressed whether in DU-145 cells, growth inhibition by boldine was associated with apoptosis induction. The results obtained, allow us to hypothesize that boldine is able to induce apoptosis by the intrinsic or mitochondrial apoptotic pathway. In fact, an increase of caspase- 3 enzyme activity occurred in DU-145 cells treated with boldine at 60-120 $\mu \mathrm{M}$ concentrations (Figure 3 ). In addition, caspase-9 was shown to be observably activated (Figure 5). The hypothesis of apoptosis induction in our experimental conditions was reinforced by a high DNA fragmentation
(Comet assay, TUNEL method) at $60-120 \mu \mathrm{M}$ concentrations (Figure 4), not correlated to LDH release (Table 1). Alternatively, the reduction of caspase cascade at higher concentration $(240 \mu \mathrm{M})$ probably switched the mode of boldine-induced cell death from apoptosis to necrosis.

The Bcl-2 family proteins govern decision steps that determine whether certain caspase family cell death proteases remain quiescent or become active [21, 22]. After 17 years, these proteins still remain today as a valid target for cancer therapy, providing successful examples for the discovery of inhibitors that target protein-protein interactions [31]. Therefore, it is significant that we observed, according previous studies [29], that the treatment with boldine at $60-120$ $\mu \mathrm{M}$ shifted the $\mathrm{Bax} / \mathrm{Bcl}-2$ ratio towards apoptotic cell death (Figure 5).

Heat-shock protein 70 (Hsp70), as a highly conserved protein, exists in all living cells and is produced following stimulation by hypoxia, ischaemia, viral infection and oxidants [32]. The protective presence of Hsp70 can be beneficial for the whole organism, if Hsp70 is expressed in normal cells, however in cancer cells, Hsp70 is a negative prognostic marker [23]. Hsp70 may participate in oncogenesis and its high expression increases drug resistance of many different types of cancer [23], including androgen-independent prostate cancer [23, 33]. The tumorigenic potential of this stress protein is correlated, at least in part, with its capacity to disable apoptosis. Elevated Hsp70 levels block the apoptotic pathway at different levels. Some literature data have suggested that Hsp70 may inhibit apoptosis by acting downstream of mitochondria and cytochrome c release [34]. This anti-apoptotic effect was explained by Hsp70mediated modulation of apoptosome [34]. In fact, Hsp70 has been showed to directly bind to the cytosolic apoptosis protease-activating factor-1 (Apaf1 ), thereby preventing the recruitment of procaspase- 9 to the apoptosome [34].

Our results, according previous studies in human invasive breast cancer cell lines, MDA-MB-231 and MDA-MB-468 [29], further address the role of boldine in the induction of Hsp70 in cancer, which might point to a potential mechanism against the antitumor and chemosensitizing effects of boldine on hormonerefractory prostate cancer. Indeed, boldine probably interacting with the regulatory elements responsible for increased expression of Hsp70 in cancer cells, as reported for other natural compounds such as 
quercetin, a well-known Hsp70 protein inhibitor [35], induced a reduction of Hsp70 expression (Figure 5A). Elucidating these mechanisms is a focus of future studies.

\section{CONCLUSION}

Taken together, these results, which can be considered as the starting point for further investigation, suggest that the aporphine alkaloid boldine induces cell death by intrinsic apoptotic pathway that probably involves the down-regulation of heat shock protein 70 (Hsp70). In future studies, other possible underlying mechanisms will be examined, aiming to offer an impulse to the development of boldine analogues with more powerful efficiency for the therapy of prostate cancer in advanced stages.

\section{CONFLICT OF INTEREST}

The authors confirm that there are no conflicts of interest.

\section{REFERENCES}

[1] American Cancer Society. http://www.cancer.org/ (accessed on $27 / 7 / 2017$ ).

[2] Stavridi F, Karapanagiotou EM, Syrigos KN. Targeted therapeutic approaches for hormone-refractory prostate cancer. Cancer Treat Rev 2010; 36(2):122-30. https://doi.org/10.1016/j.ctrv.2009.06.001

[3] Chuu CP, Kokontis JM, Hiipakka RA, Fukuchi J, Lin HP, Lin $\mathrm{CY}$, Huo C, Su LC. Androgens as therapy for androgen receptor-positive castration-resistant prostate cancer. J Biomed Sci 2011; 18(23): 63. https://doi.org/10.1186/1423-0127-18-63

[4] Hoffman-Censits J, Fu M. Chemotherapy and targeted therapies: Are we making progress in castrate-resistant prostate cancer? Semin. Oncol 2013; 40(3): 361-74. https://doi.org/10.1053/j.seminoncol.2013.04.015

[5] Higano CS, Small EJ, Schellhammer $P$, Yasothan U, Gubernick S, Kirkpatrick P, Kantoff PW. Sipuleucel-T. Nat Rev Drug Discov 2010; 9(7): 513-14. https://doi.org/10.1038/nrd3220

[6] Sartor O, Pal SK. Abiraterone and its place in the treatment of metastatic crpc. Nat Rev Clin Oncol 2013; 10(1): 6-8. https://doi.org/10.1038/nrclinonc.2012.202

[7] Ryan CJ, Smith MR, de Bono JS, Molina A, Logothetis CJ, de Souza $\mathrm{P}$, et al. Abiraterone in metastatic prostate cancer without previous chemotherapy. N Engl J Med 2013; 368(2): 138-48.

https://doi.org/10.1056/NEJMoa1209096

[8] Yakes F M, Chen J, Tan J, Yamaguchi K, Shi Y, Yu P, Qian F, Chu F, Bentzien F, Cancilla B et al. Cabozantinib (xl184), a novel met and vegfr2 inhibitor, simultaneously suppresses metastasis, angiogenesis, and tumor growth. Mol Cancer Ther 2011; 10(12): 2298-308 https://doi.org/10.1158/1535-7163.MCT-11-0264

[9] Smith DC, Smith MR, Sweeney C, Elfiky AA, Logothetis C, Corn PG, et al. Cabozantinib in patients with advanced prostate cancer: results of a phase II randomized discontinuation trial. J Clin Oncol 2013; 31(4): 412-19. https://doi.org/10.1200/JCO.2012.45.0494
[10] Yedjou CG, Mbemi AT, Noubissi F, Tchounwou SS, Tsabang $\mathrm{N}$, Payton M, Miele L, Tchounwou PB. Prostate cancer disparity, chemoprevention, and treatment by specific medicinal plants. Nutrients 2019; 11(2): pii: E336.

https://doi.org/10.3390/nu11020336

[11] Fernández J, Lagos P, Rivera $P$ and Zamorano-Ponce E. Effect of boldo (Peumus boldus Molina) infusion on lipoperoxidation induced by cisplatin in mice liver. Phytother Res 2009; 23(7): 1024-27. https://doi.org/10.1002/ptr.2746

[12] O'Brien P, Carrasco-Pozo C, Speisky H. Boldine and its antioxidant or health-promoting properties. Chem Biol Interact 2006; 159(1): 1-17.

https://doi.org/10.1016/j.cbi.2005.09.002

[13] Si Y-X, Ji S., Wanga W, Fang N-Y, Jin Q-X, Park Y-D, et al. Effects of boldine on tyrosinase: inhibition kinetics and computational simulation. Process Biochem 2013; 48: 15261.

https://doi.org/10.1016/j.procbio.2012.11.001

[14] Gerhardt D, Bertola G, Dietrich F, Figueiró F, Zanotto-Filho A, Moreira Fonseca JC, et al. Boldine induces cell cycle arrest and apoptosis in T24 human bladder cancer cell line via regulation of ERK, AKT, and GSK-3 $\beta$. Urol Oncol 2014; 32(1):36.e1-9.

https://doi.org/10.1016/j.urolonc.2013.02.012

[15] Cardile V, Avola R, Graziano ACE, Piovano M, Russo A Cytotoxicity of demalonyl thyrsiflorin $A$, a semisynthetic labdane-derived diterpenoid, to melanoma cells. Toxicol Vitro 2018; 47: 274-80. https://doi.org/10.1016/j.tiv.2017.12.012

[16] Bradford MM. A rapid and sensitive method for the quantitation of microgram quantities of protein utilizing the principle of protein-dye binding. Anal Biochem 1976; 72(7): 248-54.

https://doi.org/10.1016/0003-2697(76)90527-3

[17] Galvano F, Russo A, Cardile V, Galvano G, Vanella A, Renis $M$. DNA damage in human fibroblasts exposed to fumonisin B(1). Food Chem Toxicol 2002; 40(1): 25-31. https://doi.org/10.1016/S0278-6915(01)00083-7

[18] Russo A, C. Espinoza CL, Caggia S, Garbarino JA, Hugo Pena-Cortes H, Carvajal TM, et al. A new jasmonic acid stereoisomeric derivative induces apoptosis via reactive oxygen species in human prostate cancer cells. Cancer Lett 2012; 326(2): 199-205. https://doi.org/10.1016/j.canlet.2012.08.025

[19] Dumont A, Hehner SP, Hofmann TG, Ueffing M, Droge W, Schmitz ML. Hydrogen peroxide-induced apoptosis is CD95independent, requires the release of mitochondria-derived reactive oxygen species and the activation of NF-kappa B. Oncogene 1999; 18(3): 747-57. https://doi.org/10.1038/sj.onc.1202325

[20] Baigi MG, Brault L, Nequesque A, Beley M, Hilali RE, Gauzere $\mathrm{F}$, et al. Apoptosis/necrosis switch in two different cancer cell lines: influence of benzoquinone and hydrogen peroxide-induced oxidative stress intensity, and glutathione. Toxicol in Vitro 2008; 22(6): 1547-54. https://doi.org/10.1016/j.tiv.2008.06.008

[21] Johnstone RW, Ruefli AA, Lowe SW. Apoptosis: A link between cancer genetics and chemotherapy. Cell 2002; 108(2): 153-64 https://doi.org/10.1016/S0092-8674(02)00625-6

[22] Shi Y. Mechanisms of caspase activation and inhibition during apoptosis. Mol Cell 2002; 9(3): 459-70. https://doi.org/10.1016/S1097-2765(02)00482-3

[23] Ji F, Lv R, Zhao T. A correlation analysis between tumor imaging changes and p-AKT and HSP70 expression in tumor cells after osteosarcoma chemotherapy. Oncol Lett 2017; 14(6): 6749-753. https://doi.org/10.3892/ol.2017.7005 
[24] Kazemi Noureini S, Tanavar F. Boldine, a natural aporphine alkaloid, inhibits telomerase at non-toxic concentrations. Chem Biol Interact 2015; 231(25): 27-34. https://doi.org/10.1016/j.cbi.2015.02.020

[25] Gillis NK, McLeod HL. The pharmacogenomics of drug resistance toprotein kinase inhibitors. Drug Resist Updat 2016; 28: 28-42.

https://doi.org/10.1016/j.drup.2016.06.008

[26] Koeberle A, Werz O. Multi-target approach for natural products in inflammation. Drug Discov Today. 2014;19(12) 1871-82. https://doi.org/10.1016/j.drudis.2014.08.006

[27] Talevi A. Multi-target pharmacology: possibilities and limitations of the "skeleton key approach" from a medicinal chemist perspective. Front Pharmacol 2015; 6(22): 205. https://doi.org/10.3389/fphar.2015.00205

[28] Basmadjian C, Zhao Q, Bentouhami E, Dejehal A, Nebegil CG, Johnson RA et al. Cancer wars: natural products strike back. Front Chem 2014; 2(1): 20. https://doi.org/10.3389/fchem.2014.00020

[29] Paydar M, Kamalidehghan B, Wong YL, Wong WF, Looi CY, Mustafa MR. Evaluation of cytotoxic and chemotherapeutic properties of boldine in breast cancer using in vitro and in vivo models. Drug Des Dev Ther 2014; 8(6): 719-33. https://doi.org/10.2147/DDDT.S58178

[30] Nimmanapalli R, Perkins CL, Orlando M, O’Bryan E, Nguyen $\mathrm{D}$, Bhalla KN. Pretreatment with paclitaxel enhances Apo-2 ligand/tumor necrosis factor-related apoptosis-inducing ligand-induced apoptosis of prostate cancer cells by inducing death receptors 4 and 5 protein levels. Cancer Res 2001; 61(2): 759-63.

[31] Yang S, Mao Y, Zhang H, Xu Y, An J, Huang Z. The chemical biology of apoptosis: Revisited after 17 years. EurJ Med Chem 2019; 177: 63-75.

https://doi.org/10.1016/j.ejmech.2019.05.019

[32] Rigg RA, Healy LD, Nowak MS, Mallet J, Thierheimer MLD, Pang $J$, et al. Heat shock protein 70 regulates platelet integrin activation, granule secretion and aggregation. Am J Physiol Cell Physiol 2016; 310(7): C568-C75. https://doi.org/10.1152/ajpcell.00362.2015

[33] Ren A, Yan G, You B and Sun J. Down-regulation of mammalian sterile 20-like kinase 1 by Heat Shock Protein 70 mediates cisplatin resistance in prostate cancer cells. Cancer Res 2008; 68(7): 2266-74. https://doi.org/10.1158/0008-5472.CAN-07-6248

[34] Garrido C, Brunet M, Didelot C, Zemati Y, Schimitt E, Kroemer G. Heat Shock Proteins 27 and 70 anti-apoptotic proteins with tumorigenic properties. Cell Cycle 2006; 5(22): 2592-601.

https://doi.org/10.4161/cc.5.22.3448

[35] Wei $Y Q$, Zhao X, Kariya $Y$, Fukata H, Teshigawara K, Uchida A. Induction ofapoptosis by quercetin: involvement of heat shock protein. Cancer Res 1994; 54(18): 4952-957.

Received on 17-07-2019

Accepted on 08-08-2019

Published on 23-08-2019

https://doi.org/10.30683/1927-7229.2019.08.03

(C) 2019 Cardile et al.; Licensee Neoplasia Research.

This is an open access article licensed under the terms of the Creative Commons Attribution Non-Commercial License (http://creativecommons.org/licenses/by-nc/3.0/) which permits unrestricted, non-commercial use, distribution and reproduction in any medium, provided the work is properly cited. 